\title{
György füvesember és a Györgytea története
}

Lopes-Szabó Zsuzsanna

Pharmaherb Kft.

e-mail: lopesszabozsuzsa@gyorgytea.hu

A szakmában ismert névvé vált "Gyuri bácsi” történetét nem ismeri mindenki. Leghitelesebb forrásokból, tévhitek és szóbeszédek nélkül kívánom bemutatni azt az embert, aki olyan sokat tett az elmúlt évtizedekben a számára oly kedves gyógynövények népszerűsítése érdekében.

Egy olyan ember történetét ismerhetik meg, aki valóban a kis kosárral kezdte, az erdőből vitte őt a hite és tántoríthatatlan meggyőződése az ismertség felé.

A hagyományos gyógyászat egyik ismert képviselője, szószólója. 30 éve azon munkálkodik, hogy továbbadja azt a tudást és hitet, melyet ő érez a népi gyógyítás, azon belül a gyógynövények iránt. Ő az az ember, aki jókor volt jó helyen: épp elindult a „természethez vissza” mozgalom, felébredt a kiegészítő gyógymódok iránti igény. Részben neki köszönhető, hogy egyre növekszik azok száma, akik bíznak a gyógynövények erejében, akik tudják, hogy kicsi bajra elég egy gyógytea, és hogy a nagyobb betegségeket is könnyebben küzdjük le, ha rásegítünk a terápiára gyógynövényekkel.

Egy család története kapcsán azt a rögös utat szeretném bemutatni, amelyet végigjárt-jártunk a kiskosártól a HACCP-s üzemig, a rendszerváltástól mostanáig, egészen addig, hogy ma itt tartok Önöknek minderről előadást.

Köszönetnyilvánítás: Szabó György füvesembernek és édesapának. 